\title{
No easy answers
}

\author{
Britain's regulator has taken a sensible approach to the fraught question of what kinds of genetic testing \\ should be permitted on embryos.
}

T here is no gene for the human spirit, declared the producers of the 1997 movie Gattaca, which related the sobering tale of a eugenic community that had overestimated the usefulness of genes in predicting a person's destiny. The movie's hero, Vincent, overcomes a damning genetic prognosis and resultant discrimination to become an astronaut, while the fall guy, Jerome, fails to achieve the athletic prowess supposedly encoded in his DNA.

Gattaca echoed widespread public disquiet about the possible use and abuse of genetics in the selection of embryos that are free of particular disease-causing genes. Opinions on the matter range from those who think the market should be allowed to determine the use of such testing, as occurs in the United States, to others who would ban embryo selection altogether.

In nations that choose to regulate genetic tests, the real question is how far testing should be allowed to go. They are already used for the genetic mutations that cause cystic fibrosis, where a severely adverse outcome for the child is reasonably certain, and quite early in life. The question now arises of what to do regarding genes (such as $B R C A 1$, which leads to breast cancer) where the outcome may not be fatal and comes later. Decisions will soon have to be made regarding tests for genes whose implications are even less specific.

How should societies wrestling with this question proceed? Different nations have sharply different regulatory arrangements, often heavily influenced by their histories of genetics and eugenics. In Germany, for example, an Embryo Protection Law currently prohibits the genetic testing of embryos altogether.

In the United States, by contrast, memories of forced sterilization when eugenics was in fashion early in the twentieth century led to a series of Supreme Court judgements that support the individual's right to procreate. Despite the concerns of some religious groups, this has made the federal government reluctant to restrict such freedom. The result has been a free-for-all that doesn't even offer anxious would-be parents adequate means of assessing the scientific merit of the tests to which they are subjected.

The middle ground is being sought in Britain, where the Human Fertilisation and Embryology Authority (HFEA) regulates both fertility clinics and embryo research. At a meeting in Belfast last week, the authority ruled that the testing of embryos should be permitted, in certain circumstances, for genes that are not certain to cause severe illness, but merely likely to do so.

The HFEA has a reasonable track record of consulting openly with people of many different backgrounds and views. Its job is to interpret the law in the light of technological developments and take the necessary decisions about what should or should not be permitted. The authority's 18 members represent a mix of scientists, ethicists, law experts, theologians and members of the public. It strives to be independent, and neither its chair nor its deputy chair may be scientists or clinicians involved in fertility treatment.

Last week's decision followed a fact-gathering exercise, publication of a consultation document, a public meeting held last year in London, and consideration of the issue by the author-
"The HFEA ruled that the testing of embryos should be permitted for genes that are not certain to cause disease, but are merely likely to do so." ity's ethics and law committee. The HFEA already allowed genetic tests to be used for conditions where a single gene is certain to lead to disease; the new decision extends this to conditions where the gene is only likely to cause disease, and allows affected families and their clinicians to have a say in how severe they consider the disease to be. For the time being, clinics will have to apply to a licence committee for permission to treat each family that approaches them.

The decision could not have pleased everyone, and critics voiced strenuous objections to what they regard as a 'slippery slope' towards the more permissive use of genetic testing. But the decision to allow individual families and their doctors some discretion in determining just what constitutes a serious condition is preferable to the alternative of decreeing prescribed lists of tests that are banned or permitted; the latter path would fall far closer to state-mandated eugenics. The authority should be applauded for finding a middle road that will allow this potentially valuable technology to move forwards, under careful supervision.

\section{Infection biology}

\section{Immunology and microbiology come together to fight disease.}

$t$ is hardly surprising that scientific papers on human pathogens are often peppered with military analogies. Traditionally, the study of infectious disease has been considered as a conflict in which pathogens are the enemy, to be sought out and destroyed. The success of antibiotics in the twentieth century reinforced the notion that infectious diseases could be defeated, if only we could find enough ways to kill the microbes that cause them.

Battles still need to be fought, and the report in this issue of the discovery of a potentially new class of antibiotic (see pages 293 and 358) may yield some valuable new weapons. But outright victory looks increasing unlikely. A surge in strains of resistant bacteria - such as methicillin-resistant Staphylococcus aureus (MRSA) means that an increasing number of bacterial infections cannot be treated effectively. And the growth in the number of emerging 